\title{
Claudia Pretellin: Citlali Fabián: mestiza de yalálag
}

E 1 trabajo de Citlali Fabián está guiado por la curiosidad, esencia latente que se advierte al conocerla. Su interés, a grandes rasgos, va de la mano con un estado de identidad que no se limita al hecho de ser mexicana, oaxaqueña, yalalteca, sino ella misma. Su relación con la práctica fotográfica es herencia familiar. Su padre, dueño de un estudio fotográfico en Oaxaca, la introdujo a la noble labor del cuarto oscuro, donde Fabián aprendió las cualidades que ella describe como mágicas en el revelado de imágenes fotográficas. Más tarde, y gracias a su cercanía con el Centro Fotográfico Manuel Álvarez Bravo en Oaxaca, Fabián comenzó a explorar de manera independiente lo que, más que una afición, se convirtió en un llamado de su propia expresión creativa. El deseo de ser fotógrafa se hizo completamente oficial cuando, alejándose del hogar, Fabián se mudó a Xalapa para cursar la licenciatura en Fotografía en la Universidad Veracruzana, bajo la enseñanza de fotógrafos como Byron Brauchli, Miguel Femat y Helena Neme.

Al conversar con Fabián sobre sus referencias visuales, quizá resulte obvio que la respuesta apunta a la obra de Graciela Iturbide o a la de Lola Álvarez Bravo. De esta última, más que observar el trabajo previo que realizó en Yalálag, absorbe los relatos sobre su experiencia oaxaqueña. Aunque pareciera complejo hallar la influencia de tan aclamadas artistas en su obra personal (puesto que Fabián aprehende con una estética definida), su aprendizaje no se limita a la fórmula, se enfoca en lo fundamental: el tiempo poético de
Iturbide y la mirada documental de Bravo.

En 2014, mientras estudiaba la maestría en Artes Visuales en la Academia de San Carlos dentro del programa de la Universidad Nacional Autónoma de México, Fabián comenzó su serie Mestiza atraída por las cualidades técnicas del colodión húmedo, proceso inventado a finales del siglo XIX y aún vigente en tiempos de la era

Fabián sitúa a sus sujetos frente a la cámara, ofreciendo un espacio de empoderamiento que solo se logra cuando quien observa y quien es observado establecen una relación personal. Esta relación, facilitada por el artesanal proceso de producir la imagen y el tiempo para lograr fijarla, permite a ambas partes establecer un diálogo íntimo.

digital. La fotógrafa tuvo la idea de hacer representaciones de antiguas deidades zapotecas, de incorporar elementos que formaron parte de su identidad, y pronto lo que comenzó como un proceso colaborativo con amigas y familiares se convirtió en un estudio no solo de su herencia genética, sino de autorrepresentación por medio del aparato fotográfico.

En esta serie, Fabián sitúa a sus sujetos frente a la cámara, ofreciendo un espacio de empoderamiento que solo se logra cuando quien observa y quien es observado esta- 
blecen una relación personal. Esta relación, facilitada por el artesanal proceso de producir la imagen y el tiempo para lograr fijarla, permite a ambas partes establecer un diálogo íntimo. Sus sujetos dan la impresión de decidir junto con ella dónde mirar; sus mestizas en ocasiones observan directo a la lente; en otras, evitan el contacto y pierden la mirada en el momento gradualmente capturado por la fotógrafa. Estas mujeres, a diferencia del frágil soporte que las contiene, ejercen con fuerza su posición frente al espectador. El simbolismo de cada imagen es definido y escenificado con propósito; cada toma es pensada y tiene un objetivo: enaltecer el pasado y continuar la tradición, no solo de su pueblo o de su género, sino de su propio medio de expresión: la fotografía y su historia. La cámara y la imagen no son únicamente el medio; ambas son tratadas con el mismo respeto brindado a los sujetos que fotografía.

A través de estas imágenes, Fabián explora su identidad auxiliada de sus modelos; cuestiona sus elementos, los compone casi con cualidades escultóricas para finalmente capturarlos con la cámara. La placa revelada le permite ver lo que no es simple a la vista y al referirse a ella asegura: "Me llamaba mucho la atención la gran gama de detalles que capturaba [...] las texturas cobran en ciertas ocasiones un volumen casi tridimensional, pero a la vez sus cualidades parecen peleadas con el color de nuestra piel; [la imagen] no es tan sensible a los colores rojos o amarillos, por lo que una piel morena la registra con suma dureza”. Quizá, diría yo, firmeza, voluntad inquebrantable que excede el fenómeno subjetivo del color de piel, mismo que acentúa nuestra propia identidad.

En su trabajo más reciente, Fabián sigue desentrañando los pliegues de sus tradiciones. Las imágenes que conforman la se-
Las cualidades únicas de la fotografía análoga han permitido a Fabián explorar la imagen permanente, aquella que, como las tradiciones de la fotógrafa, se mantiene a pesar de la irrupción cultural o tecnológica. El medio le ha ayudado a restablecer la otra mirada, a voltear la cámara y verse con ojos propios.

rie Ben'n Yalhahj / Soy de Yalálag nos llevan al lugar que la ha visto crecer, no solo como ser humano, sino como observadora mediada por la cámara. Lo que pareciera una visión nostálgica del pasado que logra apreciarse en el paisaje y los sujetos que fotografía son más bien un documento digno de una realidad, no solamente de su pueblo sino de todas aquellas comunidades que luchan por mantener $y$ construir su propia historia a pesar de la irrupción de un presente difícil de comprender. Al preguntarle cómo ha podido Yalálag mantener sus tradiciones, Fabián describe este proceso como algo del día a día: "Es imposible aislarnos del mundo exterior y estos cambios son inevitables. Hemos asimilado y transformado estos cambios desde dentro de la misma localidad. En mi obra me interesa documentar la cultura con sus transformaciones hoy en día y no sólo en Yalálag, sino en otros lugares donde las comunidades de yalaltecos se han cimentado y replicado sus tradiciones". De esta manera, el trabajo de Fabián se extiende al otro lado de la línea, ese acuerdo sociopolítico que nos divide geográficamente al norte con Estados Unidos. Este proyecto, que ahora mismo continúa en Los Ángeles, California, es apenas una introducción a un trabajo que Fabián persigue y al que ella define como "la diáspora de los yalaltecos".

Las cualidades únicas de la fotografía análoga han permitido a Fabián explorar la imagen permanente, aquella que, como las tradiciones de la fotógrafa, se mantiene a pesar de la irrupción cultural o tecnológica. El medio le ha ayudado a restablecer la otra mirada, a voltear la cámara y verse con ojos propios, una manera de reinterpretarse y reescribir una parte de la historia del complejo tema del mestizaje y de lo que erróneamente definimos como pasado indígena, puesto que aún es parte de nuestro presente como se puede apreciar en las imágenes de Fabián. Sin tratar de resolver el acertijo, ella lo advierte como una forma de resistencia que le permite elegir cómo ver y cómo ser representada. Sus imágenes de refinada calidad técnica -alcanzada gracias al constante estudio y perfeccionamiento de la fotógrafa en México y el extranjero-, construyen un entramado de significados que, aunque parecieran sencillos de identificar, abordan un discurso que toca aspectos del estado de la imagen y el medio fotográfico en un siglo en el que ambos conceptos siguen buscando definición propia.

Claudia Pretelín es doctora en Historia del Arte por la unam. Se ha especializado en la historia y la investigación de la fotografía. Ha impartido pláticas y conferencias en México, Argentina y Estados Unidos y publicado artículos en revistas como Alquimia y Revista de Arte y Diseño. 